\title{
Geochemical signatures of groundwater in the coastal aquifers of Thiruvallur district, south India
}

\author{
S. Senthilkumar • N. Balasubramanian • \\ B. Gowtham · J. F. Lawrence
}

Received: 5 April 2014/ Accepted: 16 October 2014/Published online: 4 November 2014

(C) The Author(s) 2014. This article is published with open access at Springerlink.com

\begin{abstract}
An attempt has been made to identify the chemical processes that control the hydrochemistry of groundwater in the coastal aquifers of Thiruvallur coastal village of Thiruvallur district, Tamil Nadu, south India. The parameters such as $\mathrm{pH}, \mathrm{EC}$, TDS and major ion concentrations of $\mathrm{Na}, \mathrm{K}, \mathrm{Ca}, \mathrm{Mg}, \mathrm{Cl}, \mathrm{HCO}_{3}, \mathrm{SO}_{4}$ and $\mathrm{NO}_{3}$ of the groundwater were analyzed. Abundances of these ions are in the following order $\mathrm{Na}>\mathrm{Ca}>\mathrm{Mg}>\mathrm{K}$ and $\mathrm{HCO}_{3}>$ $\mathrm{Cl}>\mathrm{SO}_{4}>\mathrm{NO}_{3}$. The dominant water types are in the order of $\mathrm{NaCl}>$ mixed $\mathrm{CaMgCl}>\mathrm{CaHCO}_{3}>\mathrm{CaNaHCO}_{3}$. Water types (mixed $\mathrm{CaHCO}_{3}$, mixed $\mathrm{CaMgCl}$ and $\mathrm{NaCl}$ ) suggest that the mixing of high salinity water caused from surface contamination sources such as irrigation return flow, domestic wastewater and septic tank effluents with existing water followed by ion exchange reaction processes, silicate weathering and evaporation are responsible for the groundwater chemistry of the study area. The above statement is further supported by Gibbs plot where most of the samples fall within the evaporation zone.
\end{abstract}

Keywords Groundwater - Geochemical facies - Ionic ratios $\cdot$ Thiruvallur coastal village $\cdot$ Tamil Nadu

\footnotetext{
S. Senthilkumar $(\bowtie) \cdot$ B. Gowtham

Department of Geology, Presidency College, Chennai 600 005, India

e-mail: siva.senthil.geo@gmail.com

N. Balasubramanian

Department of Geology, V. O. Chidambaram College, Tuticorin 628008, India

J. F. Lawrence

Department of Geology, University of Gondar, Gondar, Ethiopia
}

\section{Introduction}

Hydrogeological and geochemical studies are the basis for scientific groundwater resource management. Due to the ever increasing demand for potable and irrigation water and inadequacy of available surface water, the importance of groundwater is increasing exponentially every day (World Bank Report 2010; Selvam and Sivasubramanian 2012).

Seawater intrusion is one of the most common problems in almost all coastal aquifers around the globe (Melloul and Goldenberg 1997, 1998; Sivakumar and Elango 2008; Chidambaram et al. 2009; Mondal et al. 2010, 2011; Srinivasamoorthy et al. 2011). This phenomenon can be explained by a variety of conditions such as gentle coastal hydraulic gradients, tidal and estuarine activity, sea level rises, low infiltration, excessive withdrawal and local hydrogeological conditions (Sarma et al. 1982; Longe et al. 1987; Rajmohan et al. 2000; Barret et al. 2002; Saxena et al. 2004; Kacimov et al. 2009). The common method for assessing seawater intrusion through an aquifer in coastal belts is the periodic analysis of groundwater (Todd 1980; Kim et al. 2009; Mondal et al. 2010, 2011; Krishnakumar et al. 2012). The chemistry of groundwater is an important factor that determines its use for domestic, irrigation and industrial purposes. Interaction of groundwater with aquifer minerals through which it flows greatly controls the groundwater chemistry.

The geochemical properties of the groundwater depend on the chemistry of water in the recharge area as well as on the different geological processes that take place in the subsurface. The groundwater chemically evolves due to the interaction with aquifer minerals or by the intermixing among the different groundwater reservoirs along the flow path in the subsurface (Domenico 1972; Wallick and 
Toth1976). Jalali (2005) reported that the dissolution of carbonate minerals, cation exchange and weathering of silicates control the groundwater chemistry in semiarid region of western Iran. Degradation of groundwater quality in the coastal region generally occurs due to natural processes such as saline water intrusion, wind-driven sea spray and marine aerosols deposited on the top soil, evaporation and interaction of groundwater with brines and sedimentary formation (Sanford et al. 2007). Groundwater is the most important source for water supply in the coastal regions of Thiruvallur district. Groundwater chemistry of a region is generally not homogeneous and is controlled by geochemical processes, flow and recharge processes, evaporation, evapotranspiration and possible presence of contamination sources. Identification of various geochemical processes will help to understand the causes for changes in water quality due to the interaction with aquifer material, especially in weathered rock formations. An attempt has been made in this study to evaluate the results of hydrogeochemical study on the coastal part of Thiruvallur district of Tamil Nadu, south India.

\section{Study area}

The study area is situated in the north of Chennai city comprising blocks such as Pulal, Sholavaram, Minjur,
Villivakkam and Gummidipoondi along the east coast of Thiruvallur district. Geographically, it extends between $79^{\circ} 55^{\prime}$ and $80^{\circ} 25^{\prime} \mathrm{E}$ and $13^{\circ} 00^{\prime}$ and $13^{\circ} 35^{\prime} \mathrm{N}$ and covered by survey of India Toposheets No. 66 C 3, 66 C 4, 66 C 7 and $66 \mathrm{C} 8$ (Fig. 1). The total areal extent of the present study area is $1,402.79$ sq. km. It is surrounded by Poonamallee and Poondi blocks in the west, Kancheepuram and Chennai districts along the south, Andhra Pradesh state in the north and Bay of Bengal along the east. The study area enjoys tropical climate. The annual mean minimum and maximum temperatures are $24.3^{\circ}$ and $32.9^{\circ} \mathrm{C}$, respectively. The district receives rain under the influence of both southwest and northeast monsoons. The northeast monsoon chiefly contributes to the rainfall to the study area. The average annual rainfall is $1,291 \mathrm{~mm}$. The drainage pattern of the study area is generally sub-dentritic. Araniyar, Korattalayar, Cooum, Nagari and Nandhi are some important rivers drain along the eastern part of the study area. All the rivers are seasonal and carry substantial flows during the monsoon period. Korattaliar River water is supplied to Cholavaram and Red Hill tanks by the Anicut at Vellore Tambarambakkam.

\section{Geology}

The main geological formations occurring in the coast are upper Gondwana consisting of sand and silts that are

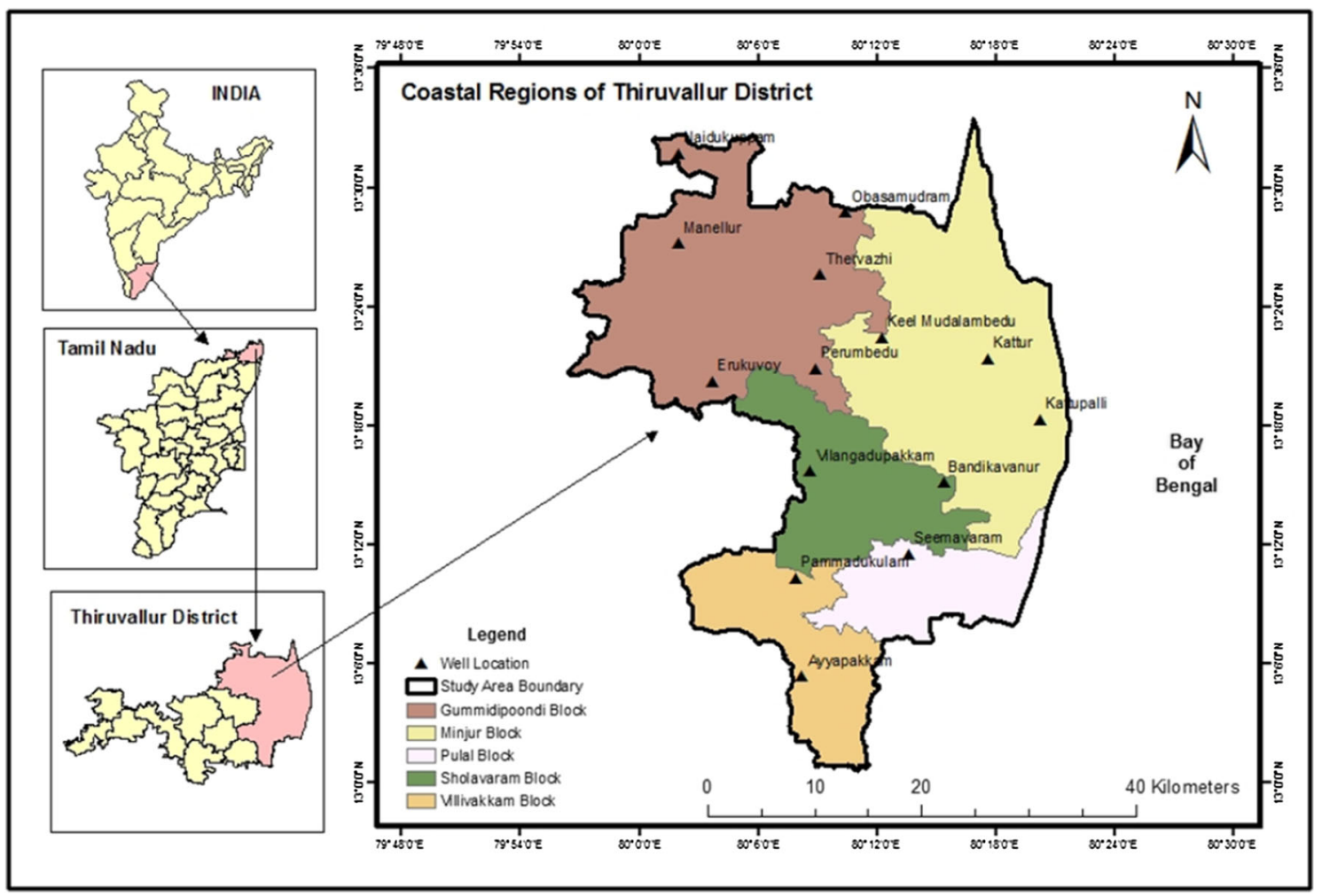

Fig. 1 Location map of the study area 
Fig. 2 Geology of the study area

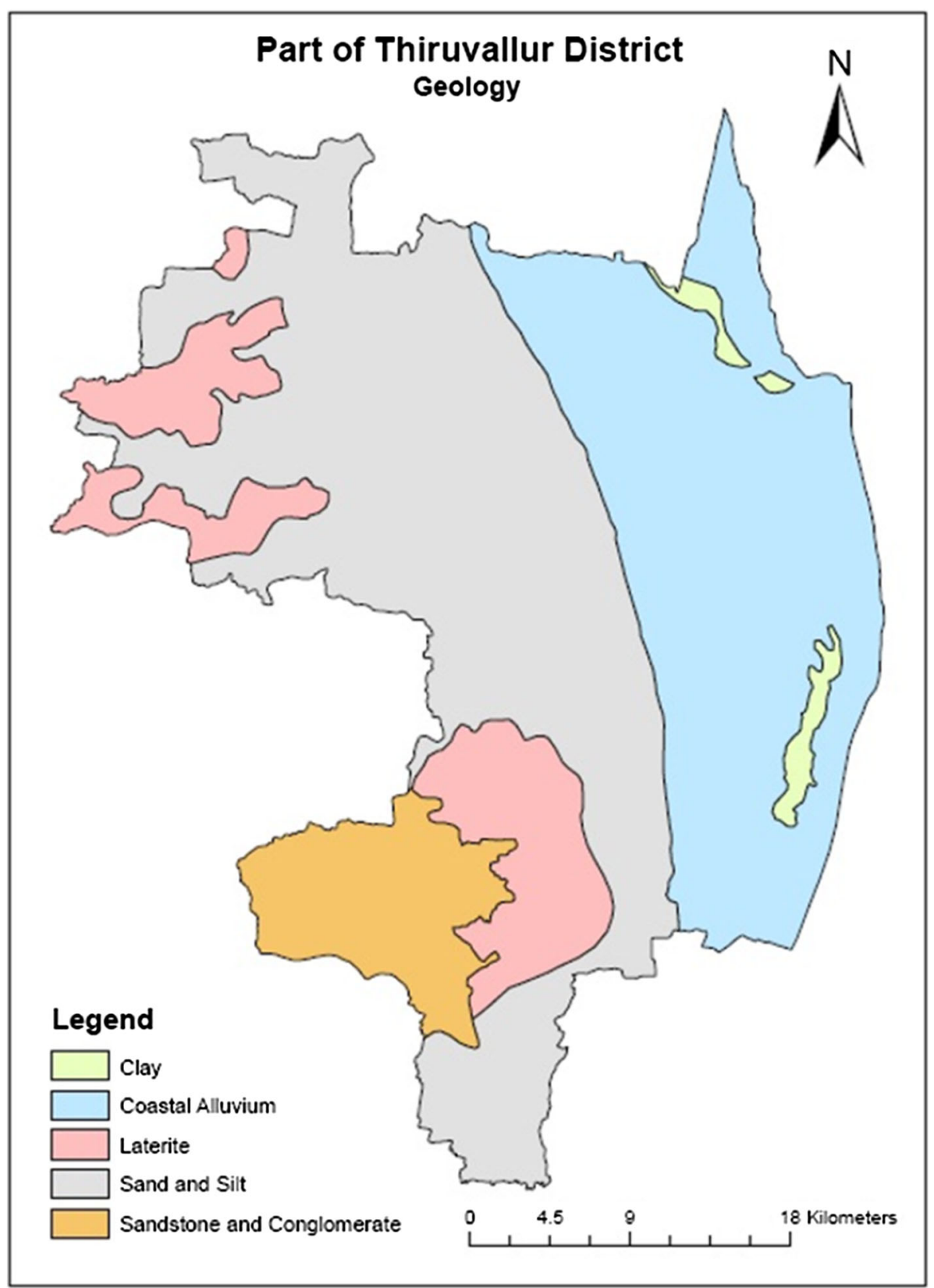

Quaternary sand and clay underlain by tertiary formations (Subramanian and Selvan 2001). The study area is equally covered by sand, silt and alluvium soil deposits. Regions around Minjur area are completely covered by coastal alluvium which lies in the east coast shoreline (Fig. 2). In rare places, clay deposition is seen. Laterite deposit covers Sholavaram area and the rest of the places are covered by sand and silt deposits which extend from the Gummudipundi block. Along the northern coast of Chennai and Thiruvallur districts, an arenaceous formation called Coromandal formation of probable Holocene age has been recorded below the beach sand. This formation is essentially a quartz arenite which at places grades in depth to clayey sand and sandy clay. As per the Central Ground Water Board (2007), Pulal and Sholavaram blocks are categorized as semi-critical and Minjur block is overexploited. Villivakkam and Gummidipoondi are classified as being in safe condition among the other blocks of the study area.

\section{Land use/land cover}

The Thiruvallur Coast consists of the following land use categories such as water bodies, settlement with vegetation and vegetation, shallow water bodies, barren land and sand 
Fig. 3 Drainage of the study area

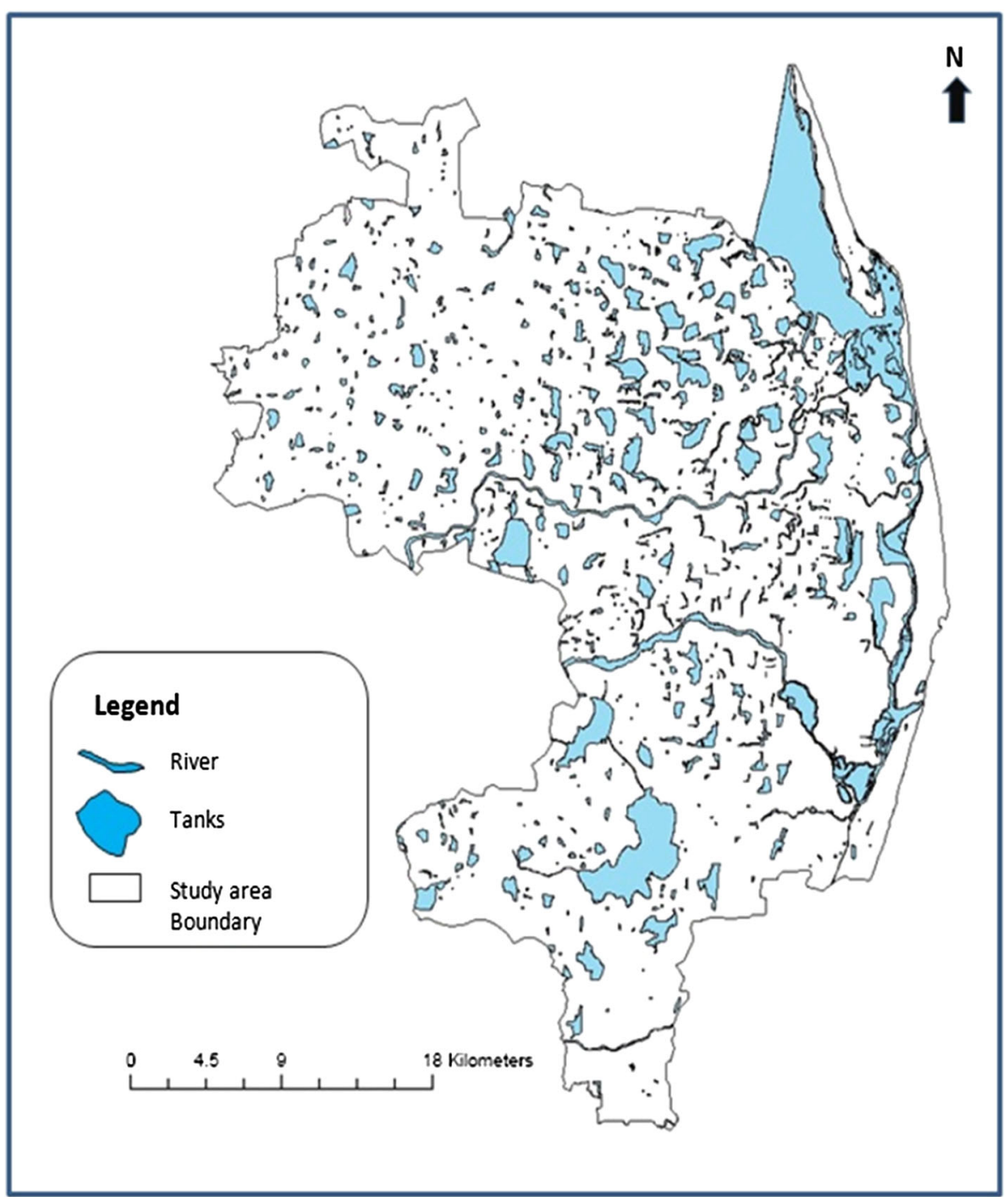

cover from the result of maximum likelihood supervised classification carried out on enhanced thematic mapper (ETM+). A major part of the study area is occupied by the vegetation cover. Around 579.27 sq. $\mathrm{km}$ of the total area is occupied by vegetation, while around 388.3608 sq. $\mathrm{km}$ is occupied by barren land, otherwise known as waste land covers. Large water bodes are seen in 187.43 sq.km, whereas shallow water bodies such as ponds and small tanks occupy 74.18 sq.km of the study area. Settlements with vegetation cover 164.83 sq. $\mathrm{km}$ of the study area. This vegetation mainly includes trees such as coconut, mango, drumstick, neem and some fruit varieties.

\section{Drainage}

The flow of subsurface water in a terrain depends on the drainage pattern. The drainage map of the study area has been prepared (Fig. 3). Araniyar, Korattalayar, Cooum,
Nagari and Nandhi are the important rivers. The drainage pattern, in general, is dendritic. All the rivers are seasonal and carry substantial flows during the monsoon period. Korattaliar River water is supplied to Cholavaram and Red Hill tanks by the Anicut at Vellore Tambarambakkam. After filling a number of tanks on its further course, the river empties into the Ennore creek a few kilometers north of Chennai. The Cooum River, flowing across the southern part of the district, has its origin in the surplus waters of the Cooum tank in Tiruvallur Taluk and also receives the surplus waters of a number of tanks. It feeds the Chembarambakkam tank through a channel and finally drains into the Bay of Bengal.

\section{Materials and methods}

Fourteen groundwater samples were collected in the entire study area during the pre-monsoon of 2012 and post- 
monsoon period of 2013. The samples were collected in 11 capacity polythene bottles. Prior to the collection, the bottles were thoroughly washed with diluted $\mathrm{HNO}_{3}$ acid, and then with distilled water before filling the bottle with the sample. $\mathrm{pH}, \mathrm{EC}$ and TDS were measured at the sample collection site using a water analysis kit (Deep Vision 191). The groundwater samples (borewell and dug well) collected were analyzed for various physicochemical parameters as described by the American public health association (APHA 1995). Sodium (Na) and potassium (K) were analyzed by flame photometer (ELICO CL354); calcium $(\mathrm{Ca})$ and magnesium $(\mathrm{Mg})$ were determined titrimetrically using EDTA standard solution. Bicarbonate $\left(\mathrm{HCO}_{3}\right)$ was estimated by titration with $\mathrm{H}_{2} \mathrm{SO}_{4}$ standard solution. Chloride $(\mathrm{Cl})$ was determined by titrating against $\mathrm{AgNO}_{3}$ standard solution and sulfate $\left(\mathrm{SO}_{4}\right)$ using spectrophotometer (ELICO SL 164).Nitrate and fluoride were determined using a spectrophotometer (Shimadzu UV1800). The analytical precision for the measurements of ions was determined by calculating the ionic balance error that varied between 5 and $10 \%$ (Domenico and Schwartz 1998).

\section{Results and discussion}

The minimum, maximum, mean and standard deviation of physicochemical parameters of chemical analysis for the groundwater samples collected in the pre- and post-monsoon period are listed in Tables 1 and 2. The $\mathrm{pH}$ of the water samples ranged from 6.9 to 8.2 with an average of 7.8 during the pre-monsoon and from 6.8 to 8.1 with an average of 7.3 during the post-monsoon period. The $\mathrm{pH}$ of groundwater is a very important indicator of its quality and controlled by the amount of dissolved $\mathrm{CO}_{2}$, carbonate and bicarbonate in groundwater (Ghandour et al. 1985). EC is an indirect measure of ionic strength and mineralization of natural water. EC of the groundwater samples of the study area ranges from 590 to $2,410 \mu \mathrm{S} / \mathrm{cm}$, with an average of $1,243 \mu \mathrm{S} / \mathrm{cm}$, and 600 to $2,478 \mu \mathrm{S} / \mathrm{cm}$, with an average of $1,273 \mu \mathrm{S} / \mathrm{cm}$ during the post- and pre-monsoon periods. Total dissolved solids (TDS), which are generally the sum of dissolved ionic concentration, vary between 413 and $1,687 \mathrm{mg} / \mathrm{l}$ with an average of 870 and 420, and 1,734 mg/l with an average of $891 \mathrm{mg} / \mathrm{l}$ during the post- and premonsoon periods. Lower pH $(6.9,7.8)$, EC $(590 \mu \mathrm{S} / \mathrm{cm}$, $600 \mu \mathrm{S} / \mathrm{cm}$ ) and TDS (413 ppm, $420 \mathrm{ppm}$ ) were recorded in the samples collected from Keel Mudalambedu, Naidukuppam and Thervazhi during the post- and pre-monsoon periods. Higher $\mathrm{pH}(8.1$ and 8.2$)$, EC $(2,410 \mu \mathrm{S} / \mathrm{cm}$ and $2,478 \mu \mathrm{S} / \mathrm{cm})$ and $\operatorname{TDS}(1,687$ and 1,734 ppm) were recorded from Konimedu, Kattur and Obasamudram during the post- and pre-monsoon periods. A high concentration of
TDS is observed (both in pre-monsoon and post-monsoon seasons) in coastal alluvium formations around Obasamudram (Loc. No. 2), Kattur (Loc. No. 8) and Kattupalli (Loc. No.9). Wells situated in other geological formations such as sandstone and alluvial plains are occupied by fresh- to medium-quality groundwater. The meager change in quality between pre-monsoon and post-monsoon indicate that groundwater has not been recharged by monsoon rainfall.

Among the cations, the minimum concentrations of $\mathrm{Na}$, $\mathrm{Ca}, \mathrm{Mg}$ and $\mathrm{K}$ are 91, 48, 12 and $11 \mathrm{mg} / \mathrm{l}$ and 93, 48, 17 and $11 \mathrm{mg} / \mathrm{l}$ during the post- and pre-monsoon period and the maximum concentrations are $371,212,70$ and $43 \mathrm{mg} / \mathrm{l}$ and 382, 204, 77 and $43 \mathrm{mg} / \mathrm{l}$, respectively, during the post- and pre-monsoon periods. The averages of these cations are 192, 112, 36 and 22 and 196, 110, 41 and 22, respectively, during the post- and pre-monsoon. The order of abundance of these cations is $\mathrm{Na}>\mathrm{Ca}>\mathrm{Mg}>\mathrm{K}$. The anion chemistry values of $\mathrm{HCO}_{3}, \mathrm{Cl}, \mathrm{SO}_{4}, \mathrm{NO}_{3}$ and $\mathrm{F}$ are minimum concentrations of $172,45,10,19$ and $0.2 \mathrm{mg} / \mathrm{l}$ and maximum values of $759,410,54,169$ and 0.4 in the post-monsoon period. In the pre-monsoon time, the analytical minimum concentrations are 201, 60, 22, 12 and $0.2 \mathrm{mg} / \mathrm{l}$ and the maximum values are 832, 430, 234, 52 and 0.4. Higher concentration of all the anionic values are in the order of $\mathrm{HCO}_{3}>\mathrm{Cl}>\mathrm{SO}_{4}>\mathrm{NO}_{3}>\mathrm{F}$.

\section{Geochemical classification}

Trilinear plotting systems are used to study the water chemistry and quality (Piper 1944). On conventional trilinear diagrams, sample values for three cations (calcium, magnesium and alkali metals-sodium and potassium) and three anions (bicarbonate, chloride and sulfate) are plotted relative to one another. These ions are generally the most common constituents in unpolluted groundwater. The fundamental interpretations of the chemical nature of water samples are based on the location of the sample ion values. This plot has been applied by several authors to understand the hydrogeochemical facies (e.g., Karanth 1991; Chidambaram 2000; Subramanian et al. 2005; Anandhan 2005; Pandian and Sankar 2007; Prasanna et al. 2010).

Distinct zones within aquifers having defined water chemistry properties are referred to as hydrochemical facies (Vasanthavigar et al. 2010). Determining the nature and distribution of hydrochemical facies can provide insight into how groundwater quality changes within and between aquifers. To understand the chemical characteristics of groundwater in the study region, groundwater samples were plotted in piper trilinear diagram (Piper 1944) using AquaCHEM software (Fig. 4). Piper plot displays that groundwater samples can be classified into various 
Table 1 Statistics of groundwater samples during pre-monsoon (all values in mg/l except $\mathrm{pH}$ and EC)

\begin{tabular}{|c|c|c|c|c|c|c|c|c|c|c|c|c|c|c|}
\hline S. no & Location name & EC & $\mathrm{PH}$ & $\mathrm{Ca}$ & $\mathrm{Mg}$ & $\mathrm{Na}$ & $\mathrm{K}$ & $\mathrm{HCO}_{3}$ & $\mathrm{CO}_{3}$ & $\mathrm{Cl}$ & $\mathrm{SO}_{4}$ & $\mathrm{NO}_{3}$ & $\mathrm{~F}$ & TDS \\
\hline 1 & Naidukuppam & 644 & 7.13 & 48 & 19 & 99 & 11 & 216 & 0 & 105 & 36 & 12 & 0.2 & 451 \\
\hline 2 & Obasamudram & 2,274 & 7.44 & 180 & 70 & 350 & 40 & 796 & 0 & 430 & 122 & 16 & 0.2 & 1,592 \\
\hline 3 & Manellur & 790 & 7.25 & 64 & 22 & 122 & 14 & 221 & 0 & 145 & 47 & 12 & 0.4 & 553 \\
\hline 4 & Thervazhi & 600 & 7.31 & 68 & 17 & 92 & 11 & 210 & 0 & 60 & 33 & 12 & 0.2 & 420 \\
\hline 5 & Keel Mudalambedu & 720 & 6.88 & 68 & 26 & 111 & 13 & 202 & 0 & 60 & 22 & 12 & 0.4 & 504 \\
\hline 6 & Erukkuvoy & 839 & 7.22 & 84 & 36 & 129 & 15 & 305 & 0 & 90 & 41 & 14 & 0.2 & 587 \\
\hline 7 & Perumbedu & 1,022 & 7.26 & 100 & 36 & 157 & 18 & 286 & 0 & 145 & 59 & 20 & 0.4 & 715 \\
\hline 8 & Kattur & 2,478 & 7.38 & 204 & 77 & 382 & 43 & 833 & 0 & 375 & 234 & 30 & 0.2 & 1,735 \\
\hline 9 & Kattupalli & 1,660 & 7.18 & 152 & 67 & 256 & 29 & 558 & 0 & 315 & 112 & 20 & 0.2 & 1,162 \\
\hline 10 & Vilangadupakkam & 923 & 7.22 & 68 & 22 & 142 & 16 & 258 & 0 & 180 & 62 & 14 & 0.2 & 646 \\
\hline 11 & Bandikavanur & 1,290 & 7.36 & 124 & 36 & 199 & 23 & 361 & 0 & 160 & 55 & 20 & 0.2 & 903 \\
\hline 12 & Seemavaram & 2,021 & 7.31 & 152 & 65 & 311 & 35 & 566 & 0 & 295 & 158 & 30 & 0.4 & 1,415 \\
\hline 13 & Pammadukulam & 910 & 8.14 & 96 & 26 & 140 & 16 & 255 & 0 & 165 & 55 & 52 & 0.4 & 637 \\
\hline 14 & Ayapakkam & 1,655 & 7.23 & 128 & 50 & 255 & 29 & 463 & 0 & 250 & 113 & 40 & 0.4 & 1,159 \\
\hline \multicolumn{2}{|c|}{ Minimum } & 600 & 6.9 & 48 & 17 & 92 & 11 & 202 & 0 & 60 & 22 & 12 & 0.2 & 420 \\
\hline \multicolumn{2}{|c|}{ Maximum } & 2,478 & 8.1 & 204 & 77 & 382 & 43 & 833 & 0 & 430 & 234 & 52 & 0.4 & 1,735 \\
\hline \multicolumn{2}{|l|}{ Mean } & $1,273.29$ & 7.31 & 109.71 & 40.63 & 196.09 & 22.28 & 395.05 & 0 & 198.21 & 82.07 & 21.71 & 0.29 & 891.3 \\
\hline \multicolumn{2}{|c|}{ Std. deviation } & 632.63 & 0.27 & 48.04 & 21.04 & 97.42 & 11.07 & 215.84 & 0 & 116.96 & 59.32 & 12.81 & 0.1 & 442.84 \\
\hline
\end{tabular}

Table 2 Statistics of groundwater samples during post-monsoon (all values in $\mathrm{mg} / \mathrm{l}$ except $\mathrm{pH}$ and EC)

\begin{tabular}{|c|c|c|c|c|c|c|c|c|c|c|c|c|c|c|}
\hline S. no & Location name & EC & $\mathrm{pH}$ & $\mathrm{Ca}$ & $\mathrm{Mg}$ & $\mathrm{Na}$ & $\mathrm{K}$ & $\mathrm{HCO}_{3}$ & $\mathrm{CO}_{3}$ & $\mathrm{Cl}$ & $\mathrm{SO}_{4}$ & $\mathrm{NO}_{3}$ & $\mathrm{~F}$ & TDS \\
\hline 1 & Naidukuppam & 590 & 7.24 & 48 & 14 & 91 & 10 & 207 & 0 & 90 & 32 & 12 & 0.2 & 413 \\
\hline 2 & Obasamudram & 2,240 & 7.36 & 172 & 70 & 345 & 39 & 753 & 0 & 410 & 129 & 14 & 0.2 & 1,568 \\
\hline 3 & Manellur & 712 & 7.13 & 68 & 17 & 110 & 12 & 199 & 0 & 130 & 40 & 12 & 0.4 & 498 \\
\hline 4 & Thervazhi & 613 & 7.22 & 64 & 14 & 94 & 11 & 172 & 0 & 75 & 36 & 10 & 0.2 & 429 \\
\hline 5 & Keel Mudalambedu & 678 & 6.92 & 76 & 17 & 104 & 12 & 190 & 0 & 45 & 19 & 12 & 0.4 & 475 \\
\hline 6 & Erukkuvoy & 814 & 7.16 & 80 & 36 & 125 & 14 & 296 & 0 & 85 & 48 & 14 & 0.2 & 570 \\
\hline 7 & Perumbedu & 998 & 7.14 & 96 & 31 & 154 & 17 & 279 & 0 & 130 & 56 & 18 & 0.4 & 699 \\
\hline 8 & Kattur & 2,410 & 7.44 & 212 & 65 & 371 & 42 & 759 & 0 & 375 & 169 & 32 & 0.2 & 1,687 \\
\hline 9 & Kattupalli & 1,642 & 7.11 & 160 & 58 & 253 & 29 & 460 & 0 & 310 & 105 & 20 & 0.2 & 1,149 \\
\hline 10 & Vilangadupakkam & 900 & 7.16 & 76 & 12 & 139 & 16 & 302 & 0 & 160 & 66 & 14 & 0.2 & 630 \\
\hline 11 & Bandikavanur & 1,266 & 7.47 & 120 & 34 & 195 & 22 & 354 & 0 & 150 & 61 & 18 & 0.2 & 886 \\
\hline 12 & Seemavaram & 1,996 & 7.29 & 156 & 65 & 307 & 35 & 559 & 0 & 280 & 166 & 28 & 0.4 & 1,397 \\
\hline 13 & Pammadukulam & 876 & 8.22 & 88 & 34 & 135 & 15 & 245 & 0 & 145 & 42 & 54 & 0.4 & 613 \\
\hline 14 & Ayapakkam & 1,670 & 7.18 & 148 & 34 & 257 & 29 & 585 & 0 & 225 & 127 & 42 & 0.4 & 1,169 \\
\hline \multicolumn{2}{|c|}{ Minimum } & 590 & 6.9 & 48 & 12 & 91 & 10 & 172 & 0 & 45 & 10 & 19 & 0.2 & 413 \\
\hline \multicolumn{2}{|c|}{ Maximum } & 2,410 & 8.2 & 212 & 70 & 371 & 42 & 759 & 0 & 410 & 54 & 169 & 1.4 & 1,687 \\
\hline \multicolumn{2}{|c|}{ Mean } & $1,243.21$ & 7.29 & 111.71 & 35.79 & 191.43 & 21.64 & 382.86 & 0 & 186.43 & 21.43 & 78.29 & 0.29 & 870.21 \\
\hline \multicolumn{2}{|c|}{ Std. Deviation } & 631.6 & 0.3 & 49.6 & 20.8 & 97.23 & 11.07 & 205.2 & 0 & 115.42 & 13.09 & 50.89 & 0.10 & 442.07 \\
\hline
\end{tabular}

chemical types for the post- and pre-monsoon periods. The dominant water types are in the order of $\mathrm{NaCl}>$ mixed $\mathrm{CaMgCl}>\mathrm{CaHCO}_{3}>\mathrm{CaNaHCO}_{3}$. However, most of the samples are clustered in the $\mathrm{NaCl}$ and $\mathrm{CaMgCl}$ segments. Water types (mixed $\mathrm{CaHCO}_{3}$, mixed $\mathrm{CaMgCl}$ and $\mathrm{NaCl}$ ) are widely present in the study area for both seasons and suggest the mixing of high salinity water caused from surface contamination sources, such as irrigation return flow, domestic wastewater and septic tank effluents with existing water followed by ion exchange reactions. However, mixed $\mathrm{CaNaHCO}_{3}$ and $\mathrm{CaHCO}_{3}$ water types suggest mineral dissolution and recharge of freshwater. 
Fig. 4 Geochemical facies of groundwater
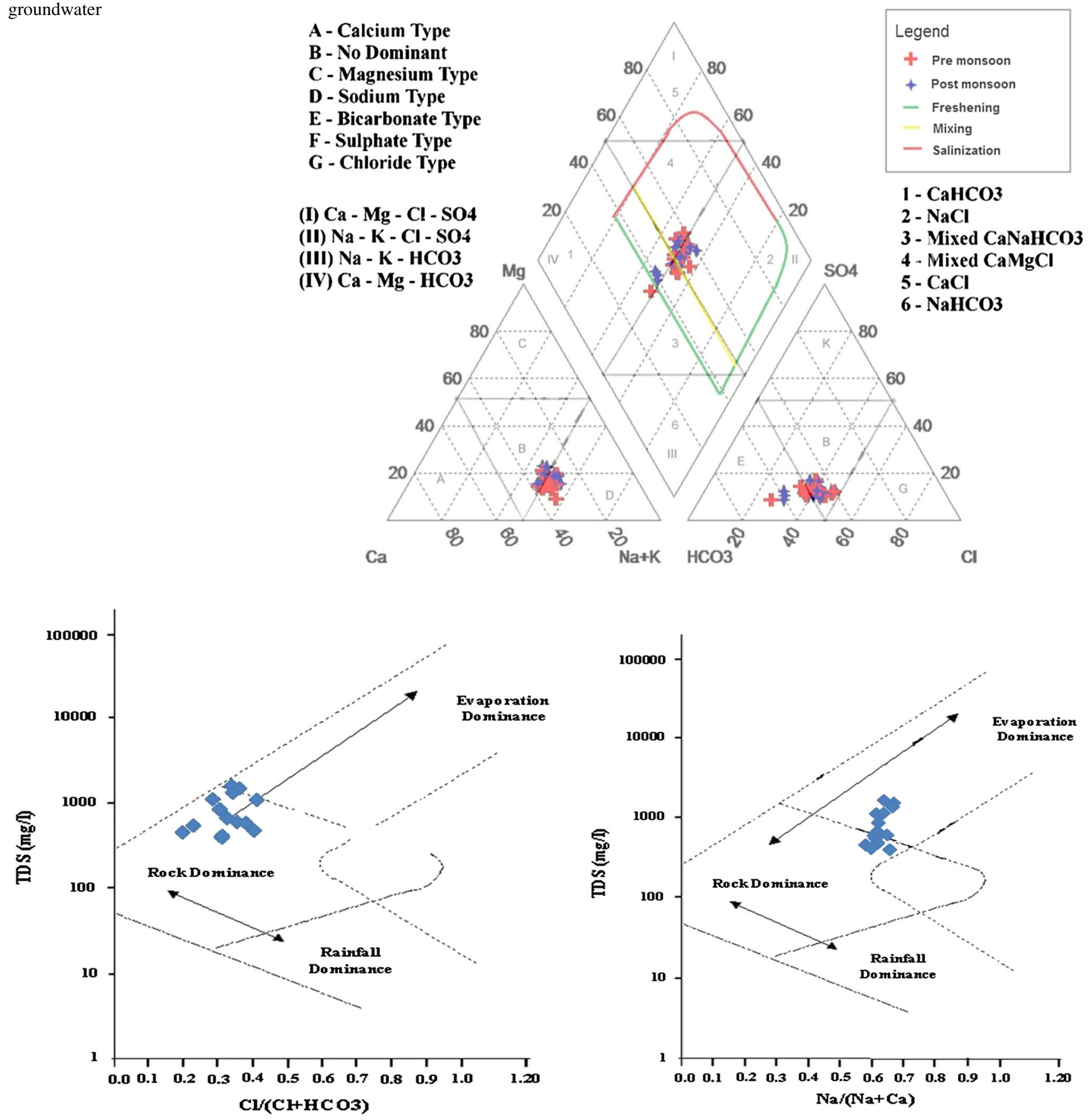

Piper Plo†

Fig. 5 Mechanism of controlling groundwater chemistry during post-monsoon

In addition to piper diagram, Gibbs plots have been used to gain better insight into hydrochemical processes such as precipitation, rock-water interaction and evaporation (Figs. 5 and 6). Gibbs (1970) demonstrated that if TDS is plotted against $\mathrm{Na} /(\mathrm{Na}+\mathrm{Ca})$, this would provide information on the mechanism controlling the chemistry of waters. Figures 5 and 6 display that groundwater samples were plotted mostly in the rock-water interaction field and a few samples in the evaporation zone for all the seasons. This observation suggests that dissolution of carbonate and silicate minerals is mostly controlled by the groundwater chemistry in the study area. However, few samples plotted in the evaporation zone reveal that surface contamination sources, for example irrigation return flow, seem to affect 

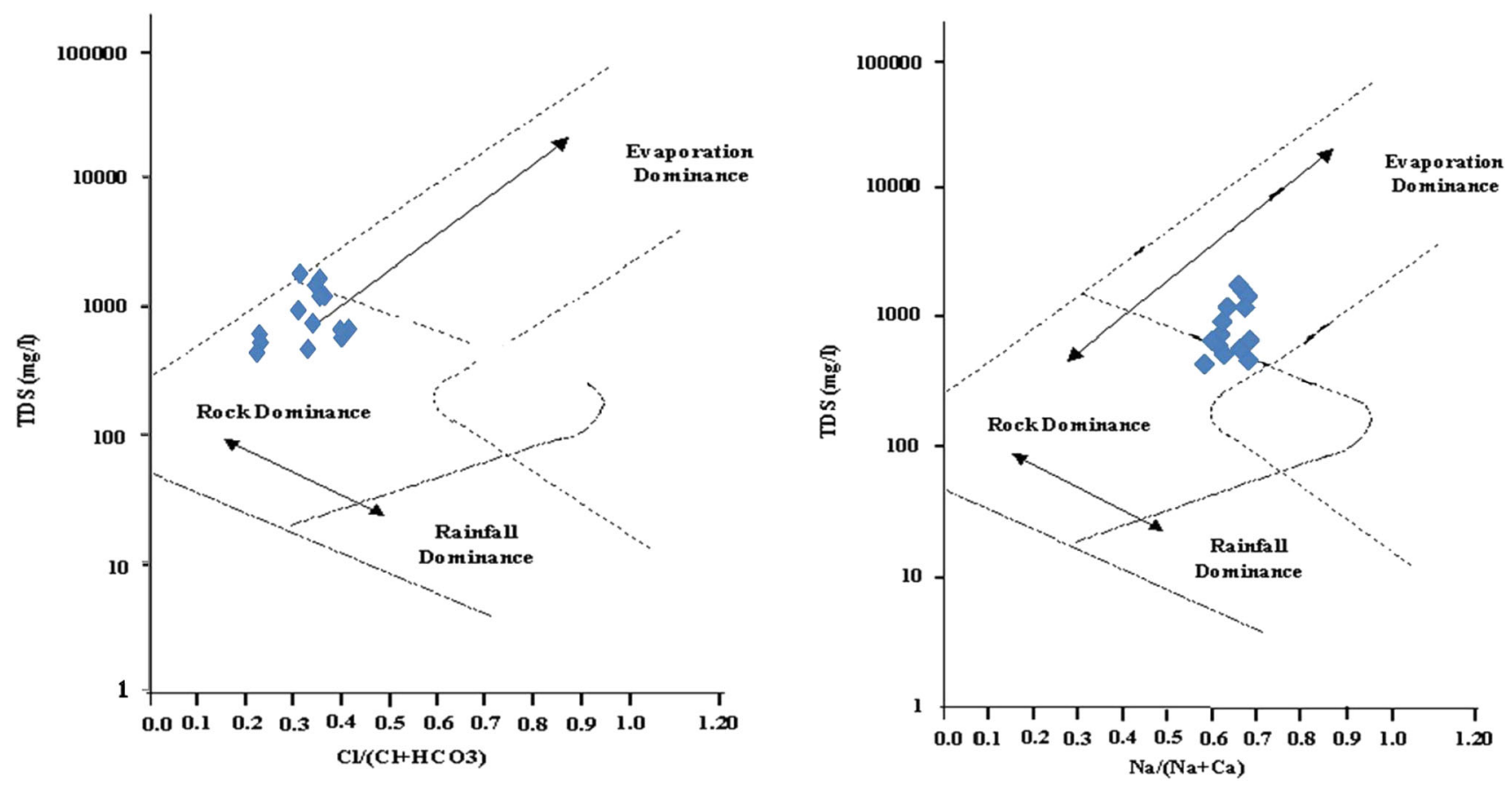

Fig. 6 Mechanism of controlling groundwater chemistry during pre-monsoon

Fig. 7 Sodium vs. chloride ionic relationship

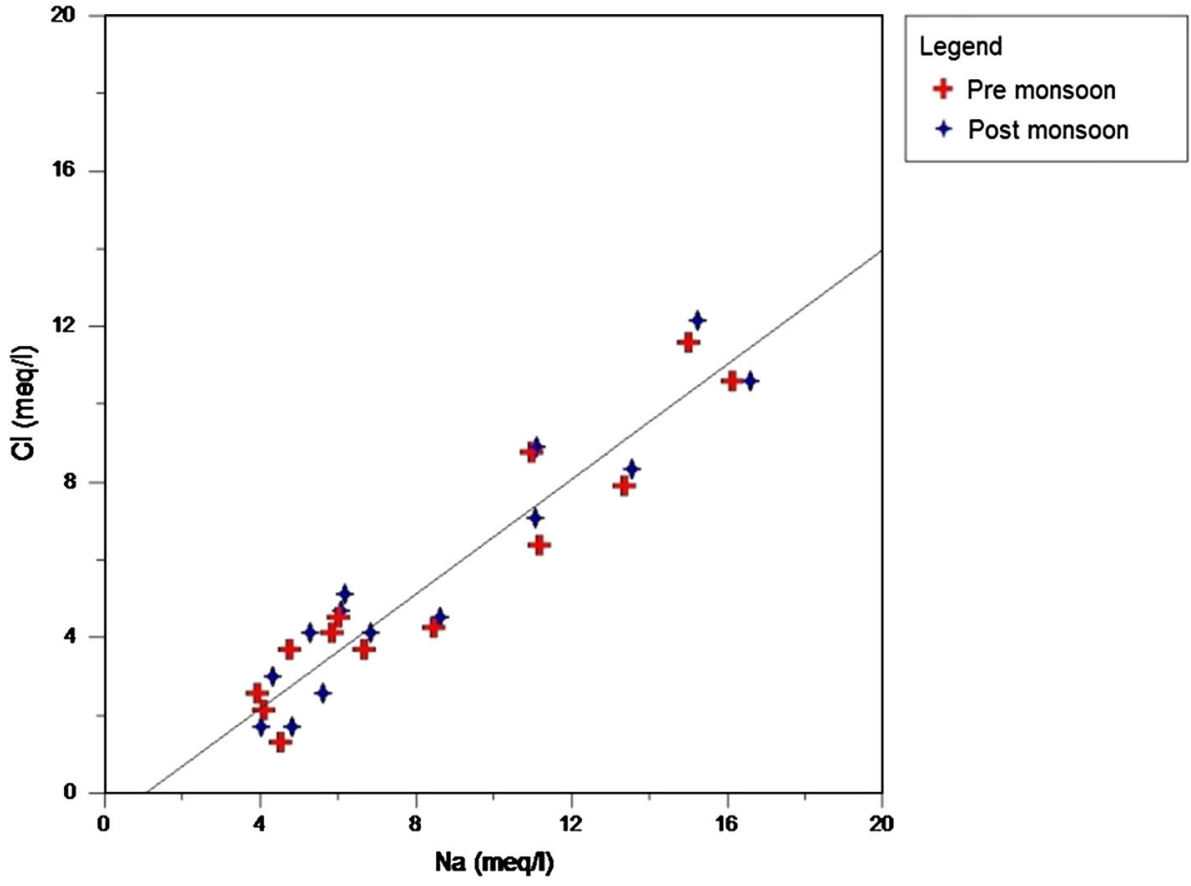

the groundwater quality in the study region. Both piper and Gibbs plots thus suggest that water chemistry is regulated by mixing of salinity water caused by surface contamination sources with existing water, ion exchange reactions, mineral dissolution and possibly evaporation.

\section{Geochemical process}

The results from the hydro chemical data are used to identify the geochemical processes and mechanisms responsible for the groundwater chemistry of the study 
Fig. 8 Sodium vs. bicarbonate ionic relationship

Fig. 9 Relationship between $\mathrm{Ca}+\mathrm{Mg}$ and $\mathrm{HCO}_{3}$
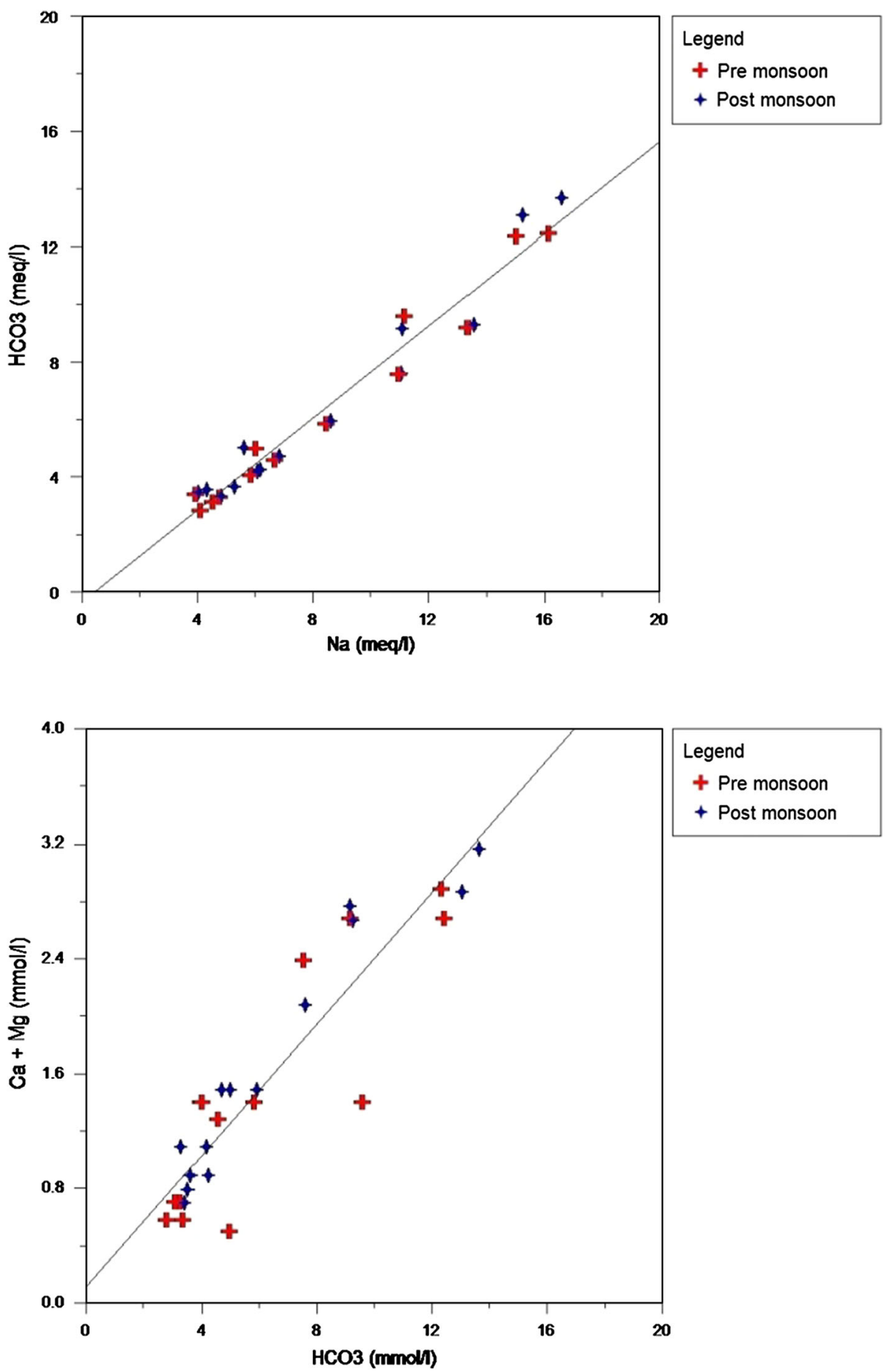

Legend

+ Pre monsoon

+ Post monsoon area. The recognized processes are explained in detail in the following sections.

The compositional relations among the dissolved ions can be used to assess the origin of solutes and the processes that result in water composition. The chemical data of water samples are plotted on $\mathrm{Na}$ vs. $\mathrm{Cl}$ scatter plot. The $\mathrm{Na}$ / $\mathrm{Cl}$ relationship has often been used to identify the mechanism for acquiring salinity and saline intrusions. Sodium and chloride show a good correlation (Fig. 7), indicating groundwater is probably controlled by water-rock interaction, most likely derived from the weathering of calcium-magnesium silicates, chiefly from calcite, plagioclase, gypsum and feldspar (Srinivasamoorthy et al. 2011). However, increased concentration of $\mathrm{HCO}_{3}$ compared to $\mathrm{Na}$ concentration (Fig. 8) in groundwater suggests that silicate weathering also occurs (Fisher and Mullican 1997). Evidences of silicate weathering can be explained by the relationships of $\mathrm{Ca}+\mathrm{Mg}$ versus $\mathrm{HCO}_{3}$ (Fig. 9). In 
Fig. 10 Relationship between $\mathrm{Ca}+\mathrm{Mg}$ and total cations

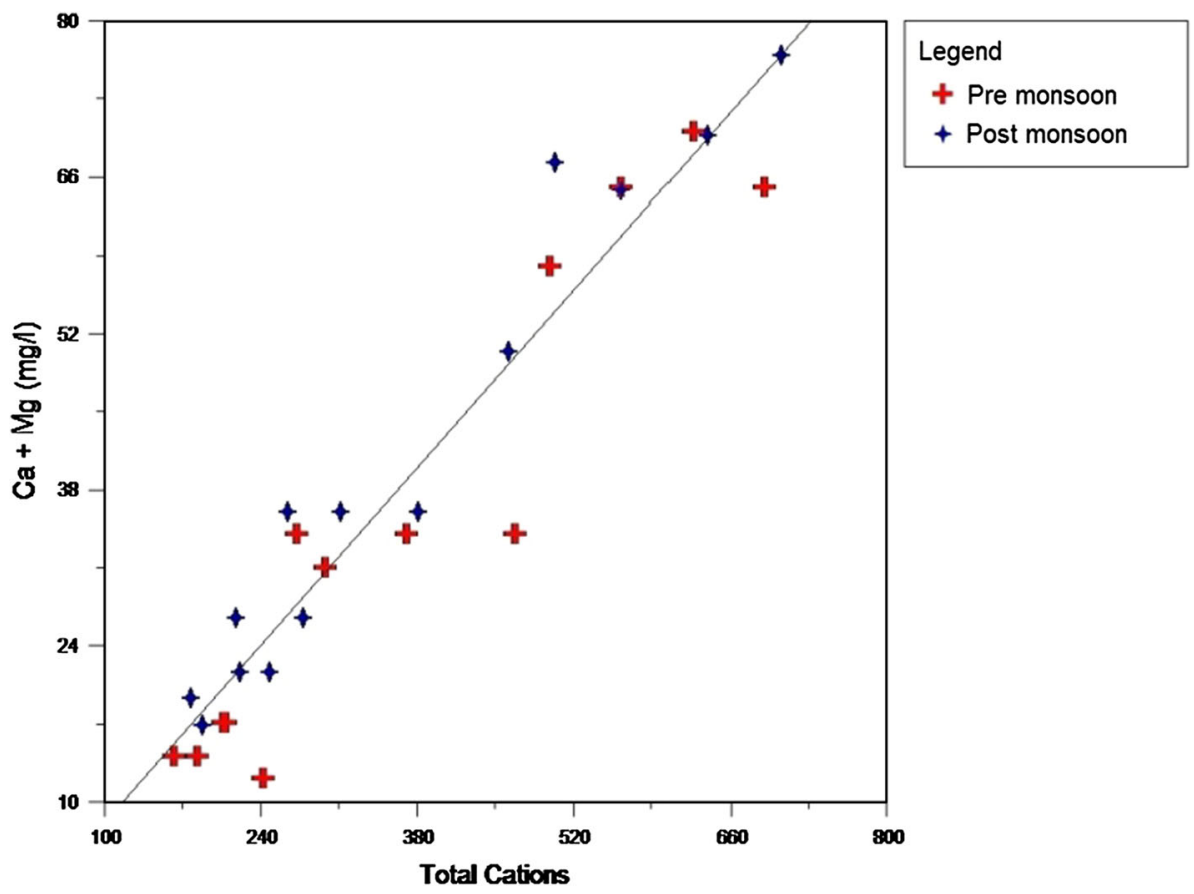

Fig. $11 \mathrm{Cl}+\mathrm{SO}_{4}$ vs. $\mathrm{Na}+\mathrm{K}$ relationship

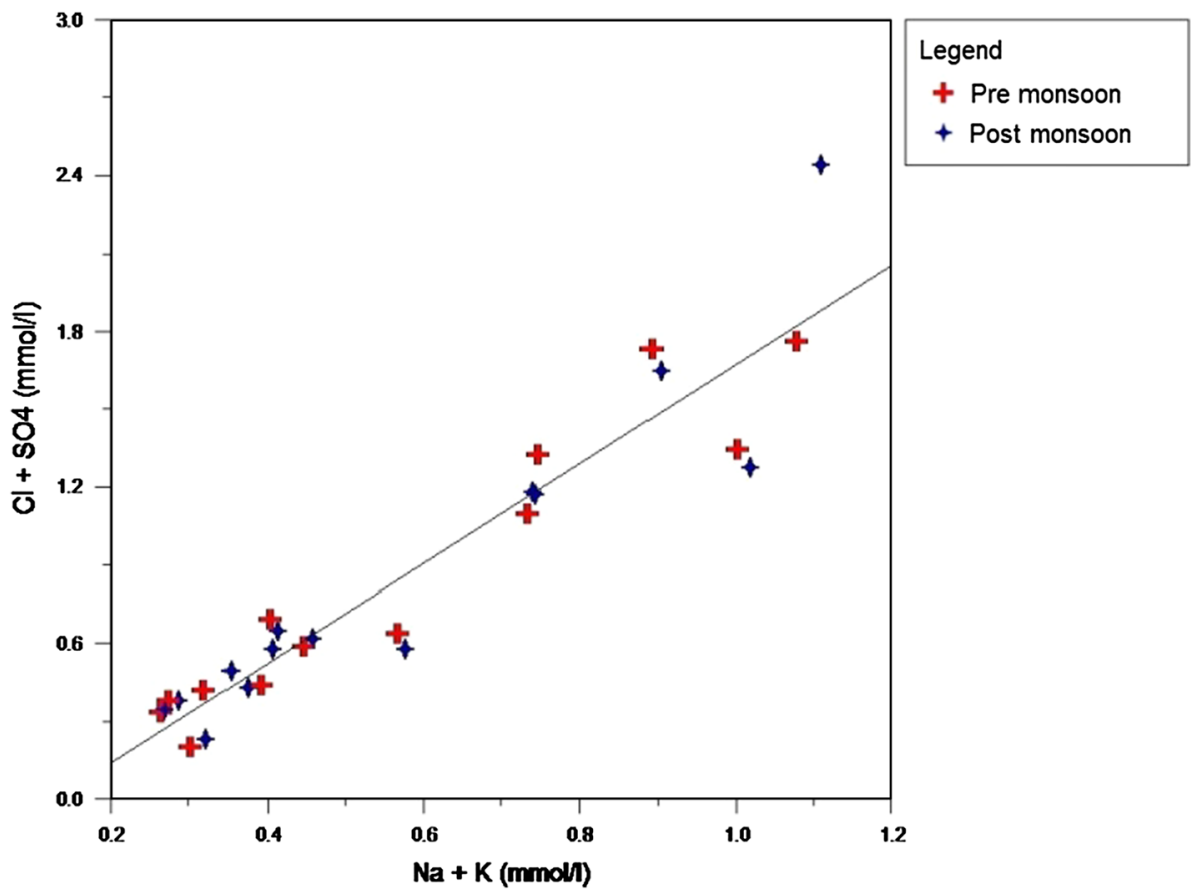

general, the evaporation process would cause an increase in concentration of all mineral species in water.

The plot of $\mathrm{Ca}+\mathrm{Mg}$ vs. total cations shows that the data fall on the $1: 1$ trend line, reflecting $\mathrm{Na}$ and $\mathrm{K}$ as the major contributor for the increase of TDS (Fig. 10). From (Fig. 11), increase in alkalinity corresponds to the simultaneous increase of $\mathrm{Cl}+\mathrm{SO}_{4}$ suggesting a common source for these ions. The increased $\mathrm{Na}$ content which is an index of weathering suggests that ions result from silicate weathering or dissolution of soil salts, the excess of $\mathrm{Na}+\mathrm{K}$ over $\mathrm{Cl}$ suggests silicate weathering and also that the higher concentration of alkalis is from sources and precipitation (Singh et al. 2011). The $\mathrm{Na}+\mathrm{K}$ vs. total cations scatter diagram (Fig. 12) of the study area shows that most of the sample points fall below the trend line. This suggests that the cations in the groundwater might have been derived from silicate weathering. 
Fig. 12 Relationship between $\mathrm{Na}+\mathrm{K}$ and total cations

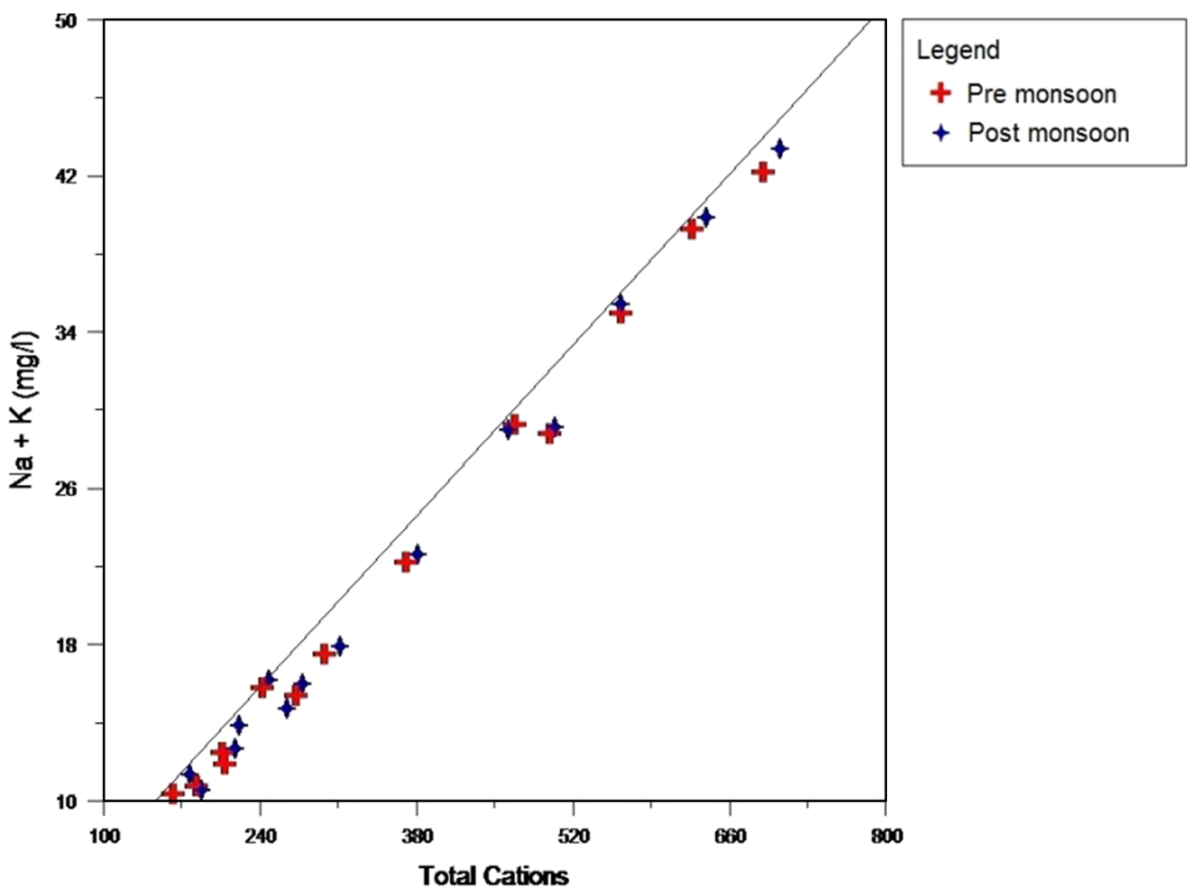

\section{Conclusion}

High TDS groundwater is present in coastal alluvium regions, while the groundwater that occurs in other geological formations is of fresh to medium quality, showing the influence of geology on groundwater quality. Most of the monsoon rainfall moves away from the study area as surface runoff, which is clearly shown by insufficient change in water quality. The order of abundance of ions are $\mathrm{Na}>\mathrm{Ca}<\mathrm{Mg}<\mathrm{K}$ and $\mathrm{Cl}<\mathrm{HCO}_{3}<\mathrm{SO}_{4}<\mathrm{NO}_{3}$. The geochemical facies of classification of groundwater shows that most of the samples are of mixed $\mathrm{NaHCO}_{3}$ type and the remaining samples are $\mathrm{Na}-\mathrm{Cl}$ type and mixed $\mathrm{Ca}-\mathrm{Mg}-$ $\mathrm{Cl}$ type. This suggests that the mixing of high salinity water caused from surface contamination sources such as irrigation return flow, domestic wastewater and septic tank effluents with existing water, followed by ion exchange reactions processes, silicate weathering and evaporation are responsible for the groundwater chemistry of the study area. The scatter plot of $\mathrm{Na} / \mathrm{Cl}$ shows good correlation, indicating that the groundwater chemistry is probably controlled by rock-water interaction. Evidences of silicate weathering can be explained by the relationships of $\mathrm{Ca}+\mathrm{Mg}$ versus $\mathrm{HCO}_{3}$. In addition to piper diagram and scatter plots, Gibbs plots were also used to understand the hydrochemical processes. In the Gibbs plots, most of the samples fall in evaporation dominance zone.

Acknowledgments The authors would like to thank the University Grants Commission (UGC), Government of India for providing the financial assistant to carry out this research work under the scheme of Major Research Project (Ref: UGC Letter No. F.No.41-1040/2012 (SR) Dated 23.07.2012). The authors also thank Dr. M. Mohamed Ibhrahim, Principal and Dr. R. Sivakumar, Head of the Department of Geology, Presidency College, Chennai, for their continuous support in bringing out this paper. The authors extend their genuine thanks to the anonymous reviewers for their valuable suggestions in improving the quality of the paper.

Open Access This article is distributed under the terms of the Creative Commons Attribution License which permits any use, distribution, and reproduction in any medium, provided the original author(s) and the source are credited.

\section{References}

Anandhan P (2005) Hydrogeochemical studies in and around Neyveli mining region, Tamil Nadu, India, Department of Earth Sciences, Annamalai University, pp 189

APHA (1995) Standard methods for the examinations of water and wastewater, 19th edn. American Public Association, Washington

Barret B, Heinson G, Hatch M, Telfer A (2002) Geophysical methods in saline groundwater studies: locating perched water tables and fresh-water lenses. Explor Geophys 33:115-121

CGWB (2007) District groundwater brochure, Thiruvallur district, Tamil Nadu, India

Chidambaram S (2000) Hydrogeochemical studies of groundwater in Periyar district, Tamilnadu, India, Department of Geology, Annamalai University

Chidambaram S, SenthilKumar G, Prasanna MV, John Peter A, Ramanthan AL, Srinivasamoorthy K (2009) A study on the hydrogeology and hydrogeochemistry of groundwater from different depths in a coastal aquifer: Annamalai Nagar, Tamilnadu, India. Environ Geol 57:59-73

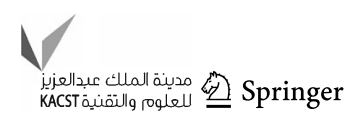


Domenico PA (1972) Concepts and models in groundwater hydrology. McGraw Hill, New York

Domenico PA and Schwartz FW (1998) Physical and chemical hydrogeology, 2nd edn, Wiley, New York, pp 506

Fisher RS, Mullican FW (1997) Hydrochemical evolution of sodiumsulfate and sodium-chloride groundwater beneath the Northern Chihuahuan Desert, Trans- Pecos, Texas, USA. Hydrogeol J 10(4):455-474

Ghandour EIM, Khalil JB, Atta SA (1985) Distribution of carbonates, bicarbonates and $\mathrm{pH}$ values in groundwater of the Nile delta region, Egypt. Groundwater 23:35-41

Gibbs RJ (1970) Mechanisms controlling world water chemistry. Science 17:1088-1090

Jalali M (2005) Major ion chemistry of ground waters in the Bahar area, Hamadan, Western Iran. J Env Geo 47:763-772

Kacimov AR, Sherif MM, Perret JS, Al-Mushikhi (2009) Control of sea-water intrusion by salt-water pumping: Coast of Oman. Hydrogeol J 17(3):541-558. doi:10.1007/s10040-008-0425-8

Karanth KR (1991) Impact of human activities on hydrogeological environments. J Geol Soc India 38(2):195-206

Kim KL, Park YS, Kim GP, Park KH (2009) Dynamic freshwatersaline water interaction in the coastal zone of Jeju Island, SouthKorea. Hydrogeol J 17:617-629

KrishnaKumar S, Chandrasekar N, Seralathan P, Prince S, Godson MNS (2012) Hydrogeochemical study of shallow carbonate aquifers, Rameswaram Island, India. Environ Monit Assess 184(7):4127-4138

Longe EO, Malomo S, Olorunniwo MA (1987) Hydrogeology of lagos metropolis. Afr J Earth Sci Technol 6(2):163-174

Melloul AJ, Goldenberg LC (1997) Monitoring of seawater intrusion in coastal aquifers: basics and local concerns. J Environ Manage 51:73-86

Melloul LC, Goldenberg AJ (1998) Early-indicator signals of groundwater contamination: the case study of seawater encroachment. Environ Geol 33(4):279-288

Mondal NC, Singh VP (2011) Hydrochemical analysis of salinization for a tannery belt in Southern India. J Hydro 405(2-3):235-247

Mondal NC, Singh VP, Singh VS, Saxena VK (2010) Determining the interaction between groundwater and saline water through groundwater major ions chemistry. J Hydro 25:100-111

Pandian K, Sankar K (2007) Hydrogeochemistry and groundwater quality in the Vaippar river basin, Tamilnadu. J Geol Soc India 69(5):970-982

Piper AM (1944) A graphic procedure in the geochemical interpretation of water analysis. Trans Am Geophys Union 25:914-923

Prasanna MV, Chidambaram S, Shahul Hameed A, Srinivasamoorthy K (2010) Study of evaluation of groundwater in Gadilam basin using hydrogeochemical and isotope data. Environ Monit Assess 168:63-90
Rajmohan N, Elango L, Ramachandran S, Natrajan M (2000) Major ion correlation in groundwater of Kancheepuram Region, south India. Indian J Environ Prot 20(3):188-193

Sanford W, Langevin C, Polemio M, Povinec P (2007) A new focus on groundwater-seawater interactions, vol 312, IAHS Publications. ISBN 978-1-901502-04-6

Sarma VVJ, Prasad NVBSS, Prasad R (1982) The geochemistry of groundwater along Visakhatnam-Bhimilipatnam coast with regard to their utility in drinking, domestic and irrigation purposes. J Explor Geophy 2(4):37-52

Saxena VK, Mondal NC, Singh VS (2004) Identification of sea-water ingress using strontium and boron in Krishna Delta, India. Curr Sci 86:586-590

Selvam S, Sivasubramanian P (2012) Groundwater potential zone identification using geoelectrical survey: a case study from Medak district, Andhra Pradesh, India. Inter J Geomat Geosci 3(1):55-62

Singh A, Tewary BK, Sinha A (2011) Hydrochemistry and quality assessment of groundwater in part of Noida metropolitan city, Uttarpradesh. J Geol Soc India 78:523-540

Sivakumar C, Elango L (2008) Assessment of water quality in Kalpakkam region, Tamil Nadu. Nat Environ Poll Technol 7(4):687-691

Srinivasamoorthy K, Vasanthavigar M, Chidambaram S, Anandhan P, Sarma VS (2011) Characterisation of groundwater chemistry in an eastern coastal area of Cuddalore district, Tamil Nadu. J Geol Soc India 78(6):549-558

Subramanian KS, Selvan TA (2001) Geology of Tamil Nadu and Pondicherry, Published Geol. Soc. India, Bangalore, pp 159-166. ISBN:81-85867-47-X

Subramanian T, Elango L, Damodarasamy SR (2005) Groundwater quality and its suitability for drinking and agricultural use in Chithar river basin, Tamilnadu, India. Environ Geol 47:1099-1110

Todd DK (1980) Groundwater hydrology, 2nd edn. Wiley, New York

Vasanthavigar M, Srinivasamoorthy K, Vijayaragavan K, Rajiv Ganthi R, Chidambaram S, Anandhan P, Manivannan R, Vasudevan S (2010) Application of water quality index for groundwater quality assessment: Thirumanimuttar sub-basin, Tamilnadu, India. Environ Monit Assess 171:595-609. doi:10. 1007/s10661-009-1302-1

Wallick EI, Toth J (1976) Methods of regional groundwater flow analysis with suggestions for the use of environmental isotope and hydrochemical data in groundwater hydrology, pp 37-64

World Bank Report (2010) Deep wells and prudence: towards pragmatic action for addressing groundwater overexploitation in India, The World Bank, Washington Report No. 51676 